\title{
TRANSPUNEREA MIȘCĂRILOR FUNCŢIONALE ALE MILITARILOR ÎN ANTRENAMENTELE SPECIFICE CrossFit
}

\author{
TRANSLATING THE FUNCTIONAL MOVEMENTS \\ OF THE MILITARY INTO SPECIFIC CrOsSFit TRAINING
}

\author{
Lt.col.instr.sup.dr. George-Florin BĂIŢAN*
}

\begin{abstract}
CrossFit-ul este un program de pregătire fizică de marcă, ,amplu, general și cuprinzător”, incluzând o serie întreagă de exerciții și antrenamente fizice, cu creșteri progresive ale intensității, acesta putând fi o formă eficientă de exerciții fizice pentru militarii care caută o rutină diversă de antrenament. Bazându-se pe biomecanica corpului uman, transpusă în mișcări și exerciții funcționale, care permit îndeplinirea sarcinilor zilnice în mod eficient, variate în mod constant și executate la o intensitate ridicată, CrossFit-ul poate avea, de asemenea, efecte mentale și emoționale pozitive, ridicând nivelul de certitudine al militarului, în raport cu propriile abilități, capacități și judecăți. CrossFit-ul înseamnă mult mai mult decât să tragi de fiare în sala de forță, este o modalitate excelentă de a obține forma sportivă, de a crește masa musculară sau de a pierde în greutate și de a trăi un stil de viață sănătos. Comunitatea CrossFit este bine cunoscută pentru relațiile strânse care există între membrii săi, pentru promovarea patriotismului, precum și pentru sprijinul acordat comunității locale și veteranilor armatei, depunând eforturi într-o varietate de moduri, pentru a susține aceste valori.
\end{abstract}

CrossFit is a branded physical training program that is "extensive, general, and comprehensive", including a series of exercises and workouts with increasing intensity, which can be an effective form of exercise for military personnel seeking a various training routine. Based on the biomechanics of the human body translated into functional movements and exercises, which allow the daily tasks to be performed efficiently, constantly varied and performed at a high intensity, CrossFit can also have positive mental and emotional effects, raising the level of certainty of the military in relation to their own abilities, capabilities and judgments. CrossFit means a lot more than just pulling the strings in the gym; it is a great way to get in shape, gain muscle mass or lose weight, and live a healthy lifestyle. The CrossFit community is well known for its close relationships with its members, for promoting patriotism, and for supporting the local community and military veterans, working hard in a variety of ways to uphold these values.

Cuvinte-cheie: CrossFit; pregătire fizică; antrenament; educație fizică militară; mișcări funcționale; fitness.

Keywords: CrossFit; physical training; training; military physical education; functional movements; fitness.

De la crearea armatei, antrenamentul fizic a jucat un rol important în pregătirea pentru luptă a militarilor. $\mathrm{Cu}$ toate acestea, de-a lungul istoriei, metodele și mijloacele folosite în pregătirea fizică la nivelul subunităţilor de militari s-au schimbat și au evoluat, pentru ca aceștia să fie pregătiți pentru rigorile luptei terestre moderne. De la începutul acestui mileniu, realitățile luptei moderne au provocat mulți lideri militari, specialiști în domeniul educației fizice militare, care fac parte din cadrul unor organizații ale NATO, să regândească pregătirea fizică și relația acesteia cu pregătirea pentru luptă. Această gândire a condus la o renaștere

\footnotetext{
*Academia Tehnică Militară „Ferdinand I” e-mail: baitan_george_florin@yahoo.com
}

a programelor de pregătire fizică funcțională și la implementarea lor de către unele armate din cadrul NATO (Canada, SUA etc.). Acestea au făcut trecerea de la pregătirea fizică militară tradiţională, axată pe antrenamentele de anduranță, cu alergări pe distanțe lungi, la pregătirea fizică funcțională, axată pe pregătirea pentru luptă.

Deși diferite de aceste programe, dezvoltarea programului de pregătire fizică CrossFit în unele țări ale căror armate sunt în NATO s-a realizat concomitent cu trecerea unor armate la pregătirea fizică funcțională, iar, în prezent, foarte mulți membri ai armatei folosesc regulat (în timpul liber) programul CrossFit.

CrossFit-ul este atât o formă de antrenament cu o intensitate ridicată, care cuprinde atât exerciții 
fizice de bază pentru dezvoltarea calităţilor motrice (în special a forței și a rezistenței), cât și un sport competitiv. Creat în anul 1995 de către un antrenor american de fitness, Greg Glassman, cu scopul declarat de a dezvolta o condiție fizică generală și de a fi un mijloc de incluziune socială, acest tip de fitness i-ar putea pregăti cel mai bine pe militari pentru situațiile în care ar apărea orice eveniment neprevăzut care presupune o solicitare fizică (incluzând aici necunoscutul).

În anul 1995, Greg Glassman a deschis prima sală de sport afiliată CrossFit, în orașul Santa Cruz din California (SUA), iar în anul 2001, și-a prezentat programul de fitness pe internet $^{1}$ și a început să publice un jurnal și să țină seminarii la o sală de sport din localitate. De atunci, CrossFit-ul a crescut continuu, ajungând, în prezent, la peste 15 mii de persoane afiliate în întreaga lume. Fondatorul a atribuit această creștere a programului său de fitness, pe de o parte, lansării site-ului său web, iar, pe de altă parte, începerii conflictelor militare din Irak și Afganistan. Din perspectiva lui, în acel moment oamenii au început să ia pregătirea fizică mult mai în serios ${ }^{2}$. Pe lângă aplicaţiile sale funcţionale în domeniul militar, mulţi atribuie popularitatea programului CrossFit simplității și varietăţii sale. Militarii care execută o misiune în afara țării și care se găsesc într-o zonă austeră au descoperit că programul CrossFit, deoarece nu se bazează pe un echipament sofisticat sau pe alergări pe distanțe lungi, se poate executa aproape oriunde.

Specialitatea CrossFit-ului nu este specializarea militarilor într-un anumit domeniu, în schimb, lupta corp la corp cu sau fără armamentul portabil din dotare, pentatlonul militar, jocurile sportive etc. sunt activități care îl obligă pe specialistul în educaţie fizică militară să aprofundeze câteva aspecte restrânse ale domeniului și să le dezvolte militarilor anumite trăsături caracteristice. Metoda CrossFit este unică, deoarece se concentrează pe maximizarea efectelor pe care le exercită sistemul nervos (în interacțiune cu cel endocrin) asupra organismului, pe dezvoltarea puterii, peCross-training (o metodă de antrenament care combină elemente de forță, fitness cardio-respirator și exerciții cu greutatea corporală), pe un antrenament practicat constant și care să conțină mișcări funcționale și pe dezvoltarea unor strategii de succes privind regimul alimentar.

\section{Conceptul de antrenament CrossFit}

CrossFit-ul este un stil de viață, caracterizat prin practicarea unor exerciții fizice simple și eficiente și printr-o alimentație sănătoasă. „Nutriţia poate fi considerată atât un factor pozitiv, care poate stimula sau creşte performanţa militară, cât şi unul negativ, care afectează eficienţa acţiunilor militare. Calitatea alimentelor, disponibilitatea lor, precum şi planificarea raţională a hrănirii militarilor pot contribui la îndeplinirea obiectivelor din misiuni"'. CrossFit-ul poate fi folosit pentru a atinge orice obiectiv propus, de la îmbunătățirea sănătății sau pierderea în greutate, până la obținerea unor performanțe fizice mai mari. Programul funcționează pentru toată lumea, atât pentru începători, cât și pentru cei care se antrenează de ani de zile.

Conceptele de pregătire fizică ale programului CrossFit se bazează pe trei standarde, care sunt folosite pentru a determina nivelul de pregătire fizică al militarilor. Primul standard se referă la cele zece abilităţi fizice generale şi calități motrice de bază, precum: forța, viteza, rezistența cardio-respiratorie, mobilitatea, suplețea, puterea, coordonarea, agilitatea, echilibrul și precizia. După acest standard se stabilește nivelul de pregătire al unui militar, în funcție de competența pe care o dovedește în cele zece abilităţi. Al doilea standard promovează ideea potrivit căreia nivelul pregătirii fizice este dat de obținerea unor performanțe bune la o gamă largă de sarcini fizice. CrossFit-ul se referă la acest standard ca la o „urnă pentru extrageri”. Dacă cineva ar pune într-o urnă toate sarcinile fizice care pot fi imaginate, le-ar amesteca, iar apoi ar scoate aleatoriu o sarcină din urnă, s-ar măsura nivelul de pregătire fizică al unui militar, în funcție de capacitatea lui de a face performanță în mod constant la oricare dintre sarcinile scoase din urnă. Al treilea standard este capacitatea organismului militarului de a performa pe cele trei căi metabolice care furnizează energie pentru toate activitățile umane (catabolică, anabolică și amfibolică). Conform acestui ultim standard, un militar este la fel de pregătit pe cât aceste căi metabolice au capacitatea de a sintetiza molecule cu utilizarea energiei, sau de a descompune molecule complexe prin eliberarea de energie în proces ${ }^{4}$.

Pentru a realiza obiectivele generale ale CrossFit-ului, în timpul antrenamentelor specifice, militarii sunt determinați să performeze constant 
mișcări funcționale, variate și de mare intensitate. În general, aceste mișcări se încadrează în una dintre cele trei categorii (sau modalități): de gimnastică, specifice halterelor (un sport olimpic în care sunt ridicate greutăţi, de la sol până deasupra capului) și pentru condiționarea metabolică („cardio”). Condiționarea metabolică se referă la acele dozări ale antrenamentului în care perioadele de exersare alternează cu cele de odihnă, pentru a provoca un anumit răspuns din partea organismului. Corpul are o serie de metode diferite de a obține energie, iar acest răspuns așteptat reprezintă, de obicei, maximizarea eficienței unui anumit sistem energetic ${ }^{5}$.

În cadrul unui antrenament specific CrossFit, se efectuează, mai întâi, o încălzire generală (pregătirea organismului pentru efort), apoi se dezvoltă o abilitate sau o calitate motrică, iar la final, se execută ,antrenamentul zilei” (AZ) Prin alcătuirea lui, AZ-ul variază de la o zi la alta și include, de obicei, un amestec de exerciții funcționale, efectuate cu un nivel ridicat al intensităţii, pe o durată de timp cuprinsă între 5 și 20 de minute. Antrenamentele CrossFit pot fi modificate pentru a ajuta fiecare militar să-și atingă obiectivele și pot fi adaptate pentru orice categorie de vârstă sau pentru orice nivel al pregătirii fizice. Cheia acestei metode de antrenament este ideea că CrossFit-ul reprezintă ,sportul fitness-ului”, încercând să valorifice competiția, plăcerea de a face sport și sentimentul de prietenie față de camarazii cu care militarii împărtășesc această experiență, prin ținerea scorului, cronometrarea antrenamentelor și definirea regulilor și standardelor de performanţă.

Un alt element esențial al antrenamentelor CrossFit este spiritul sportului și al competiţiei. În acest sens, majoritatea sălilor de sport în care se practică CrossFit-ul folosesc câteva acțiuni strategice, cum ar fi: afișarea unor tabele cu statistica performanțelor realizate și postarea câștigătorilor pe rețelele de socializare, folosite, mai degrabă, ca factori motivaționali pentru a crește productivitatea și satisfacţia, decât ca un sistem de recompensă. Așadar, dacă competiția te motivează să devii mai bun, iar spiritul de învingător şi dorința de a câștiga te împing să-ți depășești limitele din punct de vedere fizic, atunci CrossFit-ul se poate dovedi a fi o modalitate foarte bună care să te conducă la obținerea unor rezultate rapide.

La fel ca în cazul tuturor antrenamentelor de mare intensitate, și CrossFit-ul presupune existenţa riscului de apariţie a accidentărilor. Un studiu efectuat a constatat faptul că aproximativ 20\% dintre cei care au desfășurat antrenamente specifice CrossFit au suferit diverse traumatisme sportive, în principal leziuni acute destul de uşoare (totuşi, un procent destul de ridicat pentru o activitate recreativă $)^{7}$. Factorii care au dus la apariția acestor accidentări au fost, în principal, o tehnică incorectă de efectuare a exercițiilor și o dozare greșită a efortului.

Când vine vorba despre evitarea traumatismelor, o formă corectă de execuție este esențială. Cele mai importante aspecte la care trebuie să fii atent pentru a nu greși tehnica de execuţie sunt: rotunjirea coloanei lombare (produce o sarcină uriașă asupra mușchilor și ligamentelor din zona lombară, care nu sunt proiectați să o suporte) și o translație crescută a genunchilor spre înainte, în timpul exerciţiilor, precum genuflexiunile sau îndreptările. În timp ce te ghemuiești, dacă genunchii se deplasează spre înainte, peste nivelul degetelor de la picioare, atunci sarcina pe genunchi devine una uriaşă, iar articulația, de multe ori, pur și simplu nu poate face față. Cel mai frecvent, ambele traumatisme apar din cauza faptului că se realizează o compensare a lipsei de mobilitate și de stabilitate de la nivelul şoldurilor sau al gleznelor.

Toate exercițiile CrossFit sunt grozave atunci când acestea sunt dozate și efectuate corect. Aici, apare o problemă la antrenorii neexperimentați, care măresc prea repede volumul şi intensitatea efortului și îi determină pe militari să finalizeze toate repetările unui exercițiu, chiar dacă aceștia prezintă o stare de oboseală generală (o stare temporară de scădere a potențialului funcțional al organismului).

Când intri pentru prima dată într-o sală de fitness în care se desfãşoară antrenamente CrossFit, este posibil să auzi unele cuvinte/expresii specifice sau să vezi scrise pe o tablă anumite acronime, a căror semnificație ar fi bine să fie cunoscută, înainte de a te apuca de un astfel de program. Iată câteva dintre cele mai comune ${ }^{8}$ :

- WOD (Workout of the Day) = Antrenamentul zilei;

- EMOM (Every Minute on the Minute) = „Fiecare minut pe minut” constă în provocarea de a finaliza un anumit număr de repetări ale unui exercițiu în mai puțin de un minut. Timpul rămas după terminarea repetărilor și până la secunda 60 
este considerat a fi pauză, fiind destinat recuperării organismului. Acesta reprezintă un stil eficient de antrenament, deoarece necesită depunerea unui efort intens pentru a obține o perioadă mai mare de recuperare în timpul alocat, permițând astfel militarilor să devină creativi în întocmirea programelor de antrenament, făcându-le astfel mai dificile odată cu creșterea nivelului lor de pregătire fizică;

- AMRAP(As Many Rounds/Reps as Possible) $=$ Cât de multe serii/repetări posibile - constă în parcurgerea a cât mai multor serii/repetări dintr-o anumită secvență de antrenament sau dintr-un circuit într-o anumită perioadă de timp;

- „Box” = cuvânt care definește o sală de fitness CrossFit, dotată cu strictul necesar (materiale, aparate, instalații) pentru a efectua toate WOD-urile;

- „Ladder” = în trepte - cuvânt care definește executarea unui exercițiu în serii, în care numărul de repetări crește cu o unitate, ori de câte ori este efectuată o nouă serie (metoda creșterii continue);

- „Zone Diet” = dieta pe care CrossFit o promovează, aceasta fiind bazată pe componentele de bază ale dietei zilnice, o combinație de macronutrienți (carbohidrați, grăsimi și proteine). „Pentru reducerea grăsimii excesive din corp, combinația dintre dietă și exercițiile fizice s-a dovedit a fi cea mai eficientă metodă",;

- PR (Personal Record) = recordul personal acesta se referă la momentul în care este depășită cea mai bună performanță personală, înregistrată pentru un anumit exerciţiu fizic (de exemplu: efectuarea unui anumit număr de genuflexiuni într-un minut);

- „Hero WOD” = denumirea unor antrenamente date după numele unor eroi/veterani (de cele mai multe ori militari) care și-au sacrificat viaţa pentru țara lor.

Chiar dacă militarii nu sunt pregătiți să înceapă din plin un antrenament clasic CrossFit sau unitatea nu dispune de o bază materială suficientă în acest sens, există diverse elemente din cadrul CrossFitului care pot fi încorporate în propriile programe de antrenament ale acestora. Unul dintre aceste elemente sunt mișcările funcționale. Ele reprezintă acele mișcări pe care le faci în viața de zi cu zi, fără să îți dai seama. Când se execută o mișcare de bază într-un antrenament (cum ar fi: ghemuirea sau ridicarea unui obiect greu de pe sol), mușchii se contractă la fel ca atunci când trebuie să faci aceeași mișcare și în viața de zi cu zi, reducând astfel riscul de apariție a unor accidentări. Alte elemente care pot fi împrumutate din structura unor antrenamente CrossFit sunt metoda „EMOM” (descrisă anterior) sau metoda „Cursa contra cronometru”. Aceasta din urmă constă în efectuarea a cât mai multor repetări ale unuia sau mai multor exerciții într-un anumit interval de timp ${ }^{10}$.

\section{CrossFit-ul în relația cu armata}

Similar cu principiile antrenamentelor la disciplinele combat sau la instrucția tragerii cu armamentul din dotare, și mișcările efectuate în cadrul antrenamentelor CrossFit sunt sigure și eficiente numai atunci când sunt executate corect. Acest lucru înseamnă că militarii trebuie să-și formeze mai întâi deprinderea necesară efectuării corecte și consecvente a mișcărilor, după care să adauge intensitate atunci când efectuează acele mișcări (executate cu o greutate mai mare sau mai repede). Mai mult decât atât, stabilirea unui plan de antrenament eficient este la fel de importantă ca obținerea unor rezultate eficiente. De aceea important este ca instructorii sportivi să fie pregătiţi corespunzător pentru a stabili un program eficient de antrenament și pentru a le dezvolta militarilor o corectă mecanică a mișcării.

Implementarea unui program de pregătire fizică funcțională (baza antrenamentelor CrossFit) în cadrul unor unități operative ar trebui să se facă în trei etape, astfel ${ }^{11}$ :

- pregătirea unor instructori formatori, care în timp își vor exersa și perfecționa pregătirea tehnică, şi dobândirea echipamentului necesar. Instructorii selecționați ar trebui să fie niște lideri în cadrul unităţilor, respectați de către ceilalți militari, nefiind necesar ca aceștia să aibă o experienţă anterioară în conducerea unor programe de pregătire fizică funcțională, atâta timp cât sunt apți din punct de vedere fizic;

- construirea credibilității prin realizarea unei cercetări științifice în care să fie implicați militarii din cadrul unei subunităţi, pentru a evidenția eficiența programului. În acest timp, comandanții din unitate vor observa, vor evalua și se vor obișnui cu ideea de pregătire fizică funcțională;

- implementarea completă în întreaga unitate.

Având în vedere corpul comun de științe sportive pe care le au încorporate atât educația fizică militară din armată, cât și comunitatea CrossFit, 
există câteva aspecte din cadrul metodologiei CrossFit pe care armata le-ar putea adopta pentru a modifica, a perfecționa sau a rectifica testele de evaluare a personalului militar și, mai important, pentru a contribui la o revizuire de mult așteptată a concepției de pregătire fizică a militarilor.

Provocarea testului de evaluare a nivelului de pregătire fizică a personalului militar (abreviat: TEN.PF.PM) din Armata României este aceea de a găsi o modalitate prin care să-i determine pe militari să nu se antreneze (uneori, în mod exagerat) doar pentru mișcările specifice impuse de test. Ședințele de antrenament fizic constau, în mod obișnuit, doar în efectuarea exerciţiilor (flotări, abdomene și alergare de rezistență), care vor fi evaluate în cadrul testului. Fiind unul dintre defectele actualului TEN. PF.PM, armata trebuie să abordeze noi și variate strategii de antrenament pentru ca militarii să nu facă aceleași acțiuni motrice, identice cu ansamblul de mișcări sau de acțiuni produse de organism în cadrul TEN.PF.PM.

CrossFit-ulconținenumeroasetestedeverificare care evaluează toate formele de manifestare a calităților motrice de bază, precum și gradul de însușire a numeroase deprinderi motrice. CrossFit-ul se bazează pe o strategie de antrenament care variază în mod constant, punând accent pe furnizarea unui stimul eficient pentru fiecare serie a exerciților și pe posibilitatea recuperării după antrenament, fapt care produce creșteri semnificative ale condiției fizice. Antrenamentele zilnice sunt aproape întotdeauna diferite, dar includ mișcările fundamentale și componentele cheie ale pregătirii fizice necesare dezvoltării tuturor calităților motrice de bază. Mai simplu spus, îmbunătățirea performanței în orice mișcare nu înseamnă doar a face în mod repetat acea mișcare. Creșterea performanțelor sportive, care se obțin la cele trei probe din cadrul TEN. PF.PM, presupune îmbunătătirea tuturor sistemelor organismului implicate în realizarea respectivelor activități fizice.

Al doilea aspect se referă la programarea centralizată. În armată, specialiștii din domeniu întocmesc documentele de specialitate pentru planificarea și conducerea ședințelor de educație fizică militară. Ei se bazează pe documentele elaborate de structura centrală a acestui domeniu, din cadrul Ministerului Apărării Naționale (concepția de educație fizică în armată, regulamentul educației fizice militare, calendarul sportiv etc.), precum și pe educația, pregătirea și experiența lor personală. Într-o brigadă, pregătirea fizică a militarilor din fiecare unitate subordonată poate varia foarte mult, în funcție de îndrumarea specialistului unității.

În schimb, CrossFit-ul presupune o programare centralizată. În majoritatea sălilor afiliate, fiecare grupă de lucru, de-a lungul unei zile, va efectua exact același program de antrenament (inclusiv secvențele de încălzire și de revenire a organismului după efort). Acest program zilnic este, de obicei, conceput de un antrenor cu experiență, care deține cel mai înalt nivel de abilităţi și cunoștințe practice (certificat CrossFit - nivel4), bazându-se pe metode cheie de programare, construite în jurul pregătirii fizice generale. Există, de asemenea, numeroase site-uri web și bloguri, cu ajutorul cărora, afiliaţii CrossFit pot realiza programe de antrenament zilnice, săptămânale și lunare ${ }^{12}$.

În armată, atunci când toți militarii dintr-o unitate ar face același tip de antrenament, acest lucru ar reduce din obligațiile celor care conduc activitatea de educaţie fizică militară și le-ar permite acestora să se concentreze mai mult pe desfășurarea seriilor de exerciții. De asemenea, făcând același antrenament standardizat, la sfârșitul programului, toți militarii vor atinge obiectivele stabilite, indiferent denivelul lor de pregătire fizică. Obținerea de performanțe și producerea unor îmbunătățiri la locul de muncă constituie cheia atingerii acestui punct, dar antrenamentul în sine poate ajuta, de asemenea, la menținerea tuturor militarilor orientați către același stimul dorit. Probabil că nu fiecare unitate are încadrat un specialist cu experiență (profesor, instructor, antrenor etc.) care să conducă eficient toate activitățile de educație fizică militară, așa că programarea centralizată trebuie să fie o componentă importantă în construirea unei culturi sportive consolidate și consistente în întreaga armată.

Al treilea aspect care ar putea fi adoptat de la CrossFit este întocmirea programelor zilnice de antrenament, structurate pe niveluri, în funcție de performanțele realizate, care au și un caracter competițional. În majoritatea sălilor de sport CrossFit, se găsește o tablă mare, pe care este trecut un singur antrenament (cel care va fi făcut de către toate grupele în ziua respectivă), alături de care va fi afișat un clasament al performanțelor obținute de către toți cei care au desfăşurat deja antrenamentul în acea zi. 
Intensitatea este cheia pentru îmbunătăţirea performanței, iar variația intensității efortului este cheia pentru o condiție fizică mai bună. În unele zile, gradul de solicitare a organismului este de intensitate mare, în timp ce în altele, este moderat sau scăzut, dar atunci când concurezi împotriva camarazilor tăi sau pentru a stabili o performanță (personală sau în cadrul grupului), te vei motiva mai mult decât de obicei, ceea ce va duce la creșterea duratei și intensității efortului depus în antrenament, producând rezultate mai bune și o creștere a rezistenței la efort fizic.

Competițiaesteo componentăvitalăasuccesului în pregătirea fizică a militarilor. Într-o sală de sport CrossFit, concurezi împotriva cronometrului, împotriva propriilor tale performanțe obținute anterior, împotriva rezultatelor scrise pe tablă și împotriva colegilor din grupa ta de antrenament. Înglobarea acestor aspecte în educația fizică militară prin organizarea și gestionarea intenționată a unei competiții serioase poate crește considerabil performanțele fizice individuale și ale echipei. În acest sens, amplasarea unei table de scris într-o subunitate și desfășurarea de competiții zilnice (individuale și pe echipe) vor permite militarilor ca, prin depunerea unor eforturi fizice, să-și demonstreze calităţile de a fi remarcabili sau extrem de buni.

În legătură cu performanțele obținute, trebuie respectată mereu o regulă simplă, conform căreia militarii au nevoie în permanență de un arbitru judecător care să fie imparțial și care să-i motiveze să urmărească rezultatele realizate. TEN.PF.PM este administrat doar o dată la șase luni, ceea ce, pentru îmbunătățirea performanței, reprezintă o activitate (în care intervine sau poate interveni concurența) care se desfãşoară foarte rar. De aceea integrarea unor competiții sportive regulate în programul de instruire a militarilor, care să se execute între cele două TEN.PF.PM anuale, va duce la îmbunătățirea nivelului de pregătire fizică a acestora.

Un ultim aspect remarcat la CrossFit îl reprezintă centrul de greutate al acestuia, și anume corpul de instructori pregătiţi și certificați care conduc activitatea. A avea un antrenor cu experiență şi un raport scăzut între instructor și numărul de participanţi este ideal în orice activitate de educaţie fizică. Un număr cât mai mic de participanți le va permite profesorilor să aibă sarcini de lucru mai uşor de gestionat și mai mult timp pentru a lucra individual cu aceștia, implicându-i mai mult în diferite activităţi fizice, care s-ar putea să nu fie realizabile într-un grup mai mare. Este nevoie de timp pentru a dezvolta abilitățile de a conduce un grup în mod eficient.

Din punct de vedere logistic, specialiștii în domeniu ar trebui să poată instrui pe toată lumea eficient și în siguranță. Ei trebuie să explice tehnica de execuție a mișcărilor, să ofere fiecărui individ o opţiune adaptată la nivelul său de pregătire fizică şi să impună acele metode, astfel încât să nu existe riscul de apariție a accidentărilor inutile. Acest lucru se poate face în mod eficient și cu un grup mai mare de participanți, dar, pentru a face acest lucru, este nevoie de un antrenor cu experiență care să posede cunoștințe și abilităţi de comunicare adecvate. În acest sens, CrossFit se bazează pe un program de formare și de certificare a instructorilor pe mai multe niveluri de competență.

Pe lângă ofițerii licenţiaţi în educaţie fizică militară, pentru conducerea activităților de pregătire fizică, armata se bazează și pe instructorii sportivi de la nivelul subunităților care dețin niveluri variate de experiență în domeniu. Armata organizează anual, prin intermediul Centrului de pregătire a cadrelor militare în domeniul educaţiei fizice şi sportului în armată (CPCMDEFSA) ${ }^{13}$, cursuri de specializare cu responsabilii/instructorii cu educaţia fizică militară (pentru maiştri militari, subofiţeri şi soldați/gradați voluntari), cu scopul de a plasa antrenori certificați, „de la nivel de companie până la nivel direcție centrală/structură de învățământ, cu atribuții ce necesită niveluri de competență diferite" ${ }^{\prime \prime}$, astfel încât aceștia să poată conduce programul general de pregătire fizică a militarilor din cadrul subunității. În una dintre lucrările sale, profesorul Alin-Dumitru Pelmuș a făcut o comparație între formarea specialiștilor în pregătire fizică din Armata României și sistemele de formare ale acestora din unele armate membre ale NATO, ajungând la concluzia că ,,această manieră de formare a aşa-zisului specialist are repercusiuni grave asupra sistemului și nu încape niciun fel de comparație a acestuia cu cele ale armatelor NATO"15.

\section{Concluzii}

Principiile CrossFit-ului sunt concepute pentru a ajuta militarii să efectueze mișcările de zi cu zi cu mai multă forță și stabilitate. Antrenamentul 
unic ajută la evitarea plictiselii și creează un comportament de ataşare a militarilor, care au ajuns să iubească ședințele de pregătire. Oferă o alternativă excelentă la procesele de instruire tradiţionale și îi poate ajuta pe militari să depășească platoul de antrenament, datorită utilizării unor mișcări variate și folosirii intensității ridicate. Este o abordare fascinantă a conceptului de antrenament și toți militarii ar trebui să-l încerce măcar o dată.

Practicarea CrossFit-ului le formează militarilor o tenacitate mentală dezvoltată, pentru a se confrunta în mod eficient cu factorii stresanți, cu provocările și cu presiunea (indiferent de circumstanţele predominante), o capacitate de a depăşi epuizarea într-o varietate de antrenamente de înaltă intensitate care alcătuiesc majoritatea proceselor de instruire sistematică CrossFit. A te antrena din greu și a nu renunța dezvoltă o formă de duritate mentală și de rezistență care se pliază perfect pe caracterul luptătorului.

Desfășurarea activităţilor fizice în armată, cu mentalitatea de a fi competitiv, fie luptându-te pentru întâietate contra cronometru sau împotriva celorlalți camarazi, fie pentru a obține cele mai bune performanțe fizice personale sau premii, este un lucru benefic. De asemenea, a fi o persoană care vine grabnic în ajutorul colegilor de echipă sau al altor membri din cadrul armatei este o trăsătură morală înrădăcinată în programele de antrenament de grup CrossFit. Nu este nimic în neregulă ca antrenamentele să fie competitive, iar a fi un bun jucător de echipă cu colegii este o necesitate pentru toți militarii.

Există o orientare în rândul militarilor de a dori să se antreneze, folosind diferite mijloace ale educației fizice, pentru a descoperi cea mai eficientă și potrivită metodă de antrenament. Majoritatea militarilor vor să facă totul, nu doar să alerge pe aceeași distanță sau doar să facă aceleași flotări ori abdomene. CrossFit-ul, una dintre cele mai mari tendințe de pregătire fizică din ultimii ani, cu un succes fenomenal în ceea ce privește modul în care a promovat ideea de fitness funcţional al întregului corp, permite militarilor să-şi educe calitățile și priceperile motrice, fără a diminua ideea de progres, de provocare și de competiţie. Pentru militarii care practică sportul de performanţă sau pentru cei care excelează într-o anumită ramură sportivă, CrossFit-ul poate constitui o bază solidă a antrenamentului general. Imaginea CrossFit-ului este aceea de antrenamente efectuate la intensitate ridicată și este adevărat că nu este chiar ideal pentru cei mai slabi din punctul de vedere al nivelului de pregătire fizică sau pentru cei care doresc să facă doar o alergare uşoară și să transpire cât mai puţin.

$\mathrm{Cu}$ siguranță că armata nu trebuie să devină cel mai mare afiliat al CrossFit-ului din lume, dar există anumite mijloace, principii şi metode pe care comunitatea CrossFit le folosește pentru a-și îndeplini obiectivele urmărite și pe care educaţia fizică militară le-ar putea prelua și integra cu ușurință în pregătirea fizică a militarilor. Acest lucru ar îmbunătăţi calea pe care a pornit-o deja armata prin introducerea noii concepții de educaţie fizică și sport în Armata României, construind o armată mai puternică, mai bună și mai aptă din punct de vedere fizic.

\section{NOTE:}

1 http://CrossFit.com, accesat la 07.11.2021.

2 B. Mitchell, "CrossFit workout craze sweeps the Corps", Marine Corps Times, June 22, 2008, p. 12.

3 G.C. Ciapa, Orientări și oportunități pentru pregătirea fizică a militarilor, Editura Universităţii Naţionale de Apărare „Carol I”, București, 2019, p. 79.

4 https://ro.hrvwiki.net/wiki/Metabolic_pathway\#Maj or_metabolic_pathways, accesat la de 07.11.2021.

5 https://www.mensjournal.com/health-fitness/metabo lic-conditioning-the-key-to-better-performance, accesat la 07.11.2021.

6 În engleză: "Workout of the Day", abreviat WOD.

7 https://journals.sagepub.com/doi/full/10.1177/23259 67114531177, accesat la 08.11.2021.

8 https://www.nbcnews.com/better/lifestyle/what-cross fit-it-right-you-here-s-what-you-need-ncna1070886, accesat la 08.11.2021.

9 I. Andrei, Importanța pregătirii fizice în procesul de instruire militară, Editura Universității Naţionale de Apărare „Carol I”, București, 2015, p. 24.

$10 \mathrm{http}$ //fitworkshop.com/what-is-crossfit, accesat la 11.11.2021.

$11 \mathrm{https} / /$ garagegympower.com/crossfit-beginners-guide, accesat la 11.11.2021.

12 https://blog.feedspot.com/crossfit_blogs, accesat la 10.11.2021.

$13 \mathrm{https} / /$ unap.ro/index.php/ro/facultati-si-departamen te/centrul-de-pregatire-a-cadrelor-militare-in-domeniuleducatiei-fizice-si-sportului-in-armata, accesat la 12.11.2021.

14 A.D. Pelmuş, Educația fizică militară - trecut, actualitate și perspectivă, Editura Universității Naționale de Apărare „Carol I”, București, 2019, p. 69.

15 Ibidem, p. 70. 


\section{BIBLIOGRAFIE}

*** Regulamentul educaţiei fizice militare, Editura Centrului tehnic-editorial al armatei, Bucureşti, 2013.

Andrei I., Importanța pregătirii fizice în procesul de instruire militară, Editura Universității Naționale de Apărare „Carol I”, București, 2015.

Băițan G.F., Admiterea în instituțiile militare de învățământ din Ministerul Apărării Naționale - probele sportive, Editura Universității Naţionale de Apărare „Carol I”, București, 2020.

Ciapa G.C., Orientări şi oportunități pentru pregătirea fizică a militarilor, Editura Universității Naţionale de Apărare „Carol I”, București, 2019.

Gale C., 1600 Wods - 7 years of tried and tested functional fitness programming, Editura Lulu.com, Paperback, 2020.

Madden R., CrossFit: Military CrossFit Workouts for Beginners - Strength and Endurance Training, Kindle Edition, 2016.

Mitchell B., "CrossFit workout craze sweeps the Corps", Marine Corps Times, June 22, 2008.

Pelmuș A.D., Educația fizică militară - trecut, actualitate şi perspectivă, Editura Universității Naționale de Apărare „Carol I”, București, 2019.
Wayne V., CrossFit:The Beginner's Guide: Exercises and Techniques to lose Weight and Gain Ultimate Strength, Kindle Edition, 2016.

Williams Tj., Cross Training: 1,000 WOD's To Make You Fitter, Faster, Stronger, Editura Createspace Independent Publishing Platform, Scotts Valley, California, US, 2015.

https://ro.hrvwiki.net/wiki/Metabolic_ pathway\#Major_metabolic_pathways

https://www.mensjournal.com/health-fitness/ metabolic-conditioning-the-key-to-better-perfor mance

https://journals.sagepub.com/doi/full/10.1177/ 2325967114531177

https://www.nbcnews.com/better/lifestyle/ what-crossfit-it-right-you-here-s-what-you-needncna 1070886

http://fitworkshop.com/what-is-crossfit

https://garagegympower.com/crossfitbeginners-guide

https://blog.feedspot.com/crossfit_blogs

https://unap.ro/index.php/ro/facultati-sidepartamente/centrul-de-pregatire-a-cadrelormilitare-in-domeniul-educatiei-fizice-si-sportuluiin-armata

http://CrossFit.com

https://www.nbcnews.com/better/lifestyle/ what-crossfit-it-right-you-here-s-what-you-needncna1070886 